\title{
ON THE SYSTEMATICS OF THE WATER MITE LEBERTIA USSURIENSIS SOKOLOW, 1934 (ACARI, HYDRACHNIDIA, LEBERTIIDAE)
}

\section{Petr V. Tuzovsky}

Papanin Institute for Biology of Inland Waters of the Russian Academy of Sciences, Borok, Russia e-mail: tuz@ibiw.yaroslavl.ru

ABSTRACT: The first description of the larva and deutonymph of Lebertia ussuriensis is provided.

KEY WORDS: Water mite, Lebertiidae, Lebertia ussuriensis, morphology, larva, deutonymph, female, male.

DOI: 10.21684/0132-8077-2018-26-1-141-148

\section{INTRODUCTION}

The water mite Lebertia ussuriensis Sokolow, 1934 was described based on male and female specimens from the Prymorye Territory (Sokolow 1934, 1940). The larva and deutonymph of this species were previously unknown. The original description of this species is incomplete and insufficiently illustrated. Recent studies that utilized molecular methods (Martin et al. 2010, Pešić et al. 2017) showed that the present number of species is underestimated and that more cryptic species can be expected. The aim of the paper is to describe the larva and deutonymph and to characterize the female and male of L. ussuriensis.

Specimens were collected by the author and $\mathrm{T}$. Vshivkova in the running waters of the Asian part of Russia. Most specimens were not dissected, thus preserving natural shape of the body. For several female and male larvae, the gnathosoma was mounted in a position that allowed investigating pedipalps and chelicerae in lateral view. To obtain larvae, water mites were maintained in laboratory conditions (room temperature, natural day-night). Eggs and larvae, obtained from females, were kept individually in glass or transparent plastic containers with diameters between 10-15 $\mathrm{mm}$, and a height of $15 \mathrm{~mm}$.

Idiosomal setae are named according to Tuzovsky (1987): $F c h$ - frontales chelicerarum, $F p$ frontales pedipalporum, $V i$-verticales internae, $\mathrm{Ve}$-verticales externae, $\mathrm{O} i$-occipitales internae, $\mathrm{Oe}$-occipitales externae, $\mathrm{Hi}$-humerales internae, $\mathrm{He}$-humerales externae, $\mathrm{Hv}$-humerales ventralia, $\mathrm{Sci}$-scapulares internae, $\mathrm{Sce}$-scapulares externae, $\mathrm{Li}$-lumbales internae, $\mathrm{Le}$-lumbales externae, $\mathrm{Si}$ - sacrales internae, $\mathrm{Se}$ - sacrales externae, $\mathrm{Ci}$ caudales internae, $\mathrm{Pi}$ - praeanales internae, $\mathrm{Pe}$ praeanales externae, $A i$ - anales internae, $A e$ - anales externae.

Furthermore, the following abbreviations are used: P-1-5-pedipalp segments (trochanter, fe- mur, genu, tibia and tarsus); I-Leg-1-5-first leg, segments 1-5 (trochanter, femur, genu, tibia and tarsus) i.e. III-Leg-3 - genu of third leg; $\mathrm{C} 1-$ coxal setae located posteromedially on coxa I, C2 - coxal setae located posterolaterally on coxae I, C3 - coxal setae located posterolaterally on coxae, C4-coxal setae located anteriorly on coxae III, $\mathrm{L}$-length; $\mathrm{W}$-width. $\mathrm{N}$-number of specimens measured; all measurements are given in micrometers $(\mu \mathrm{m})$. The females were identified using the the original descriptions and revisions of Gerecke (2009) and Sabatino et al. (2010).

\section{RESULTS}

Family Lebertiidae Thor, 1900

Genus Lebertia Neuman, 1880

Lebertia ussuriensis Sokolow, 1931

Figs. 1-25

Material examined. 4 females, 4 males, 21 deutonymphs, 9 larvae, Asia, Russia, Kamchatka Province, stream following from Azhabachie Lake, July-August 1983, leg. P.V. Tuzovsky; 1 male, 2 deutonymph, Primorye Territory, Komarovka River, 17.7.1983, leg. T.S. Vshivkova; 3 males, Chukotka, Anadyr District, Belaya stream (inflow of the Anadyr River), 13 September 1987, leg. P. Tuzovsky. Larvae were reared from three females, the duration of the embryonic period was 12-14 days.

Description. Larva. Dorsal plate broad, with convex lateral margins (L/W ratio 1.15-1.40), in unengorged larvae covering large part of dorsum, simple setae long and thick, but setae $F c h$ longer than $V i$, trichobothria $F p$, Oi thin, short and equal in length (Fig. 1). Eight pairs of setae ( $\mathrm{Oe}, \mathrm{Hi}, \mathrm{He}$, $\mathrm{Sci}, \mathrm{Sce}, \mathrm{Li}, \mathrm{Le}, \mathrm{Si}$ ) situated in soft membrane. All idiosomal setae not associated with glandularia.

Coxal setae $\mathrm{C} 1$ shorter than $\mathrm{C} 2, \mathrm{C} 3$ and $\mathrm{C} 4$ subequal in length. Idiosomal setae $P i$ shorter than 


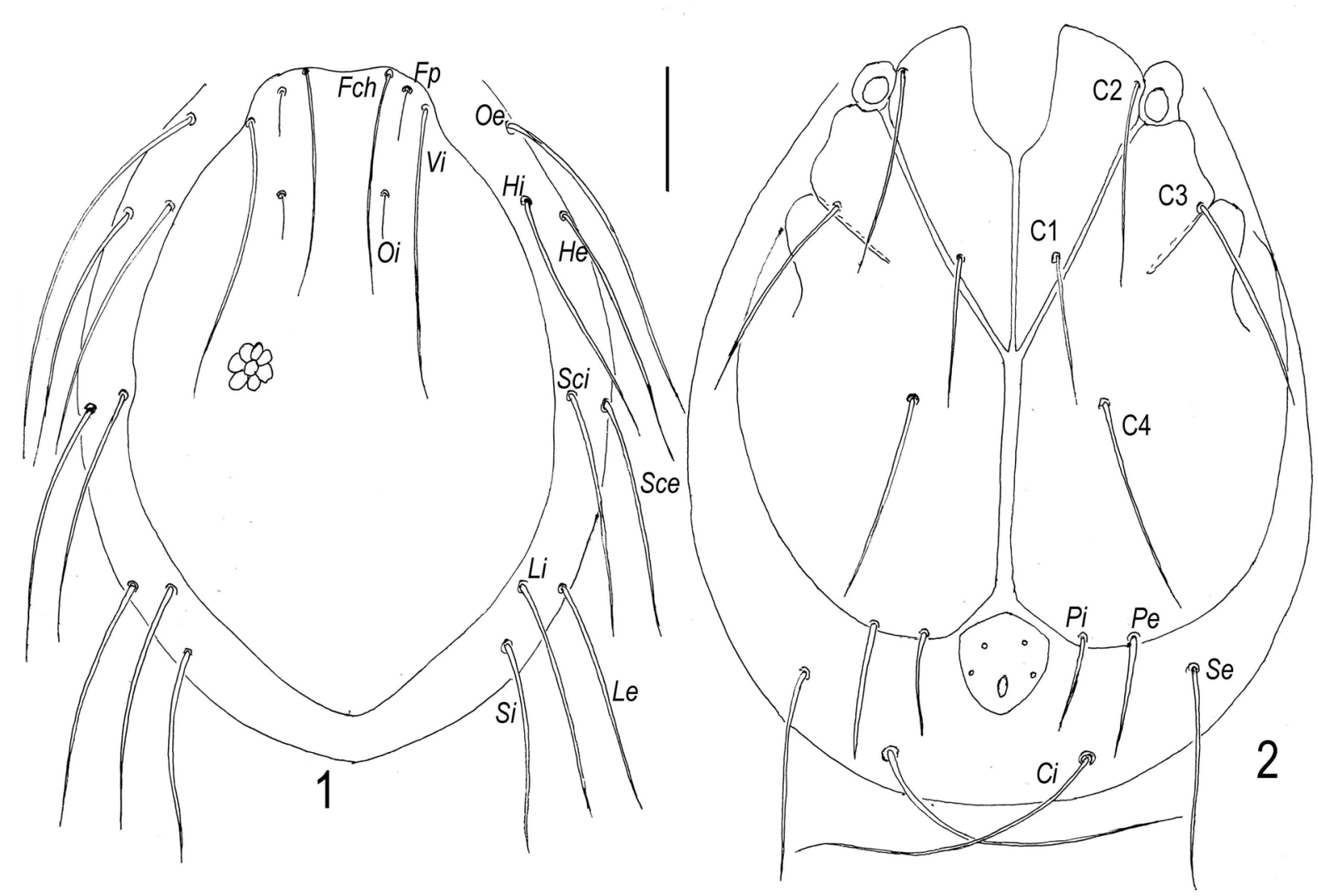

Figs. 1-2. Lebertia ussuriensis, larva: 1-dorsal view, 2-ventral view. Scale bar $50 \mu \mathrm{m}$.

$P e$ and both setae located at posterior end of coxal plate III on each side. $\mathrm{Ci}$ longest whip-like and borne on small tubercles (Fig. 2). Urstigma relatively large oval. Excretory pore plate long as wide or slightly longer (L/W ratio 1.0-1.2), excretory pore located near posterior end of plate between bases of setae $A e$, bases of setae $A i$ located close to anterior margin; distance between bases of setae $A e-A e$ almost two times longer than distance between $A i-A i$ (Figs. 3-6). Coxal shield and dorsal plate with cell-shaped reticulations.

Basal segments of chelicerae fused to each other medially (Fig. 7), with slightly convex lateral margins, their anterior edges concave. Chela small crescent-shaped with two minute subapical teeth.

Pedipalps compact (Fig. 8): P-1 very short, without seta; P-2 relatively large, with long dorsoproximal seta; P-3 with a very long, thick lateroproximal seta and relatively short, thin dorsoproximal seta; P-4 short, its length less than height, with three short, thin setae, and massive hook-like dorsodistal claw; P-5 small, with one short solenidion, two long and five relatively short unequal simple setae, one of them very short.

Shape and arrangement of setae on legs segments as shown in Figs. 9-11. Total number of setae on legs
I-III except for eupathidia as follows (number of sensillae shown in parenthesis): I-Leg-1-5: 1, 7, 5(s), 11(2s), 15(s, ac); II-Leg-1-5: 1, 7, 5(s), 11(2s), 15(s, ac); III-Leg-1-5: 1, 6, 5(s), 10(s), 11(s). Basifemur and telofemur of all legs fused to each other, with indistinct suture line. Number of heavy setae from trochanter to tarsus: I-Leg: 1, 1, 1, 1, 0; II-Leg: 0, 2, 2, 1, 0; III-Leg: 0, 1, 2, 1, 0. II-Leg-1 and III-Leg-1 each with long seta. III-Leg-4 solenidion located near centre of segment, other solenidion(a) located dorsodistally. Claws of legs I and II (Fig. 12) smaller than claws of legs III (Fig. 13).

All investigated larvae of Lebertia ussuriensis are developed without parasitism to nymphal stages.

Measurements, $n=9$. Dorsal plate L 220-270, W 190-200; setae Fch L 85-95, Fp and Oi L 13-18, $V i \mathrm{~L}$ 125-135, Oe L 130-140; Hi and He L 115-130, Sci and Sce L 95-115; Li, Le, Si and Se L 80-95, $C i$ L 115-130, Pi L 44-55, Pe L 64-80, setae C1 L 60-70, C2 and C4 80-90, C3 L 60-75; medial margins of coxae I L 75-90, medial margins of coxae II+III L 105-130; excetory pore plate L 40-50, W 38-45; capitulum L 65-70; cheliceral segments L: base 57-75, chela L 12-15; pedipalpal segments (P-1-5) L: 9-10, 25-35, 22-29, 12-17, 9-11; legs segments L: I-Leg-1-5: 32-35, 32-45, 


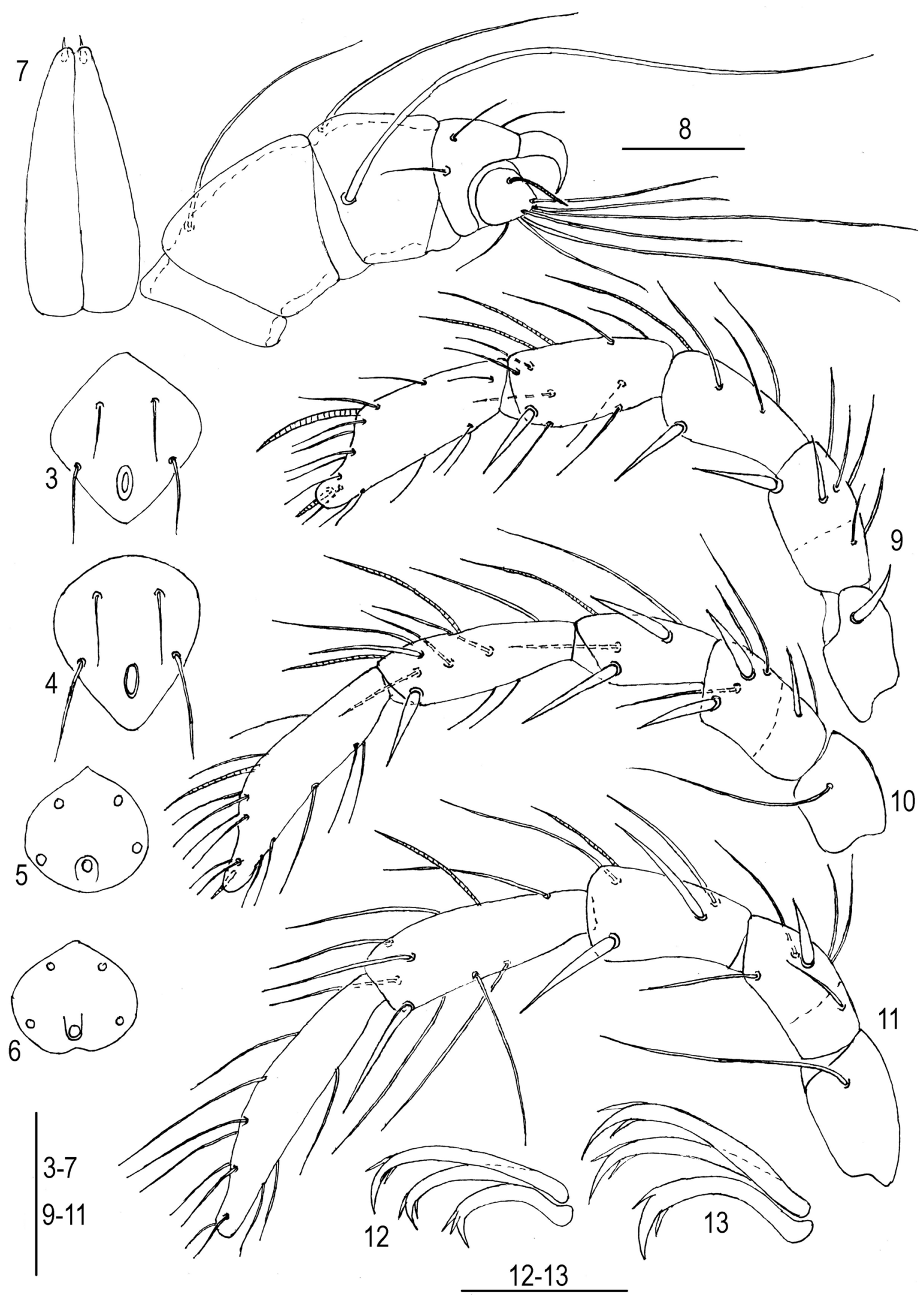

Figs. 3-13. Lebertia ussuriensis, larva: 3-6-excretory pore plate; 7-chelicera, dorsal view; 8 pedipalp; 9-leg I; 10-leg II; 11—leg III; 12 - claws of leg I; 13 — claws of leg III. Scale bars: 3-7, 9-11-50 $\mu \mathrm{m} ; 8,12,13-20 \mu \mathrm{m}$. 


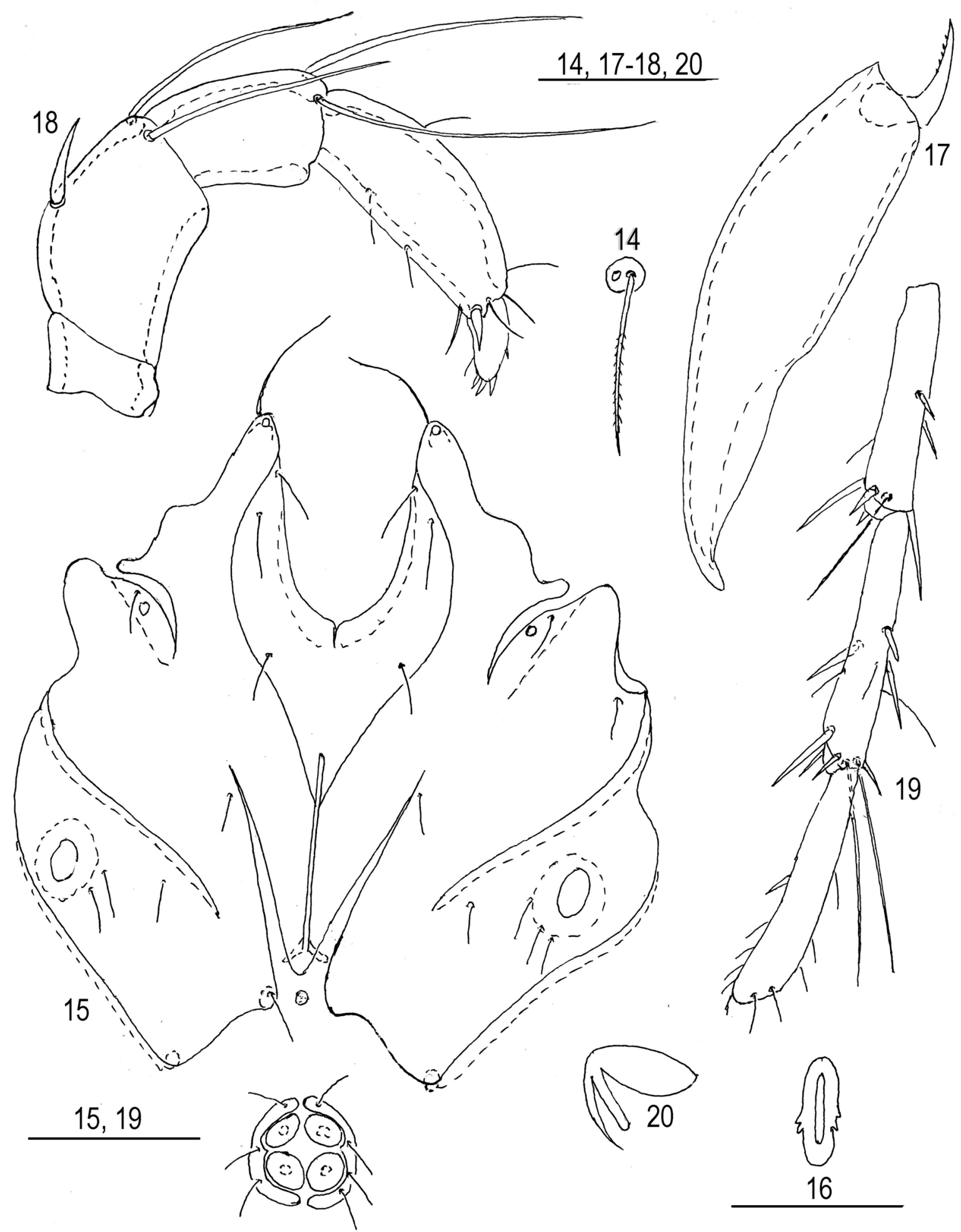

Figs. 14-20. Lebertia ussuriensis, deutonymph: 14 - seta Fch, 15-coxal shield and genital field; 16-excretory pore;

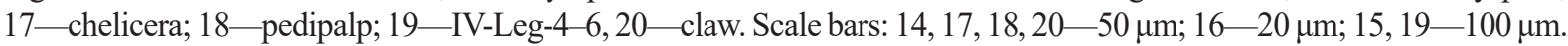

32-42, 42-55, 50-58; II-Leg-1-5: 32-36, 35-45, genus Lebertia (Tuzovsky 1987). Setae Fch (Fig. 38-42, 44-64, 51-70; III-Leg-1-5: 35-45, 38-48, 14) longer and thicker than other idiosomal setae. 41-52, 54-70, 67-90.

Deutonymph. Integument soft and finely striated. Number of idiosomal setae typical for the Trichothria $\mathrm{Fp}$, Oi and setae $\mathrm{Pi}$ not associated with glandularia, other idiosomal setae associated with glandularia. Coxal shield (Fig. 15) longer than wide 


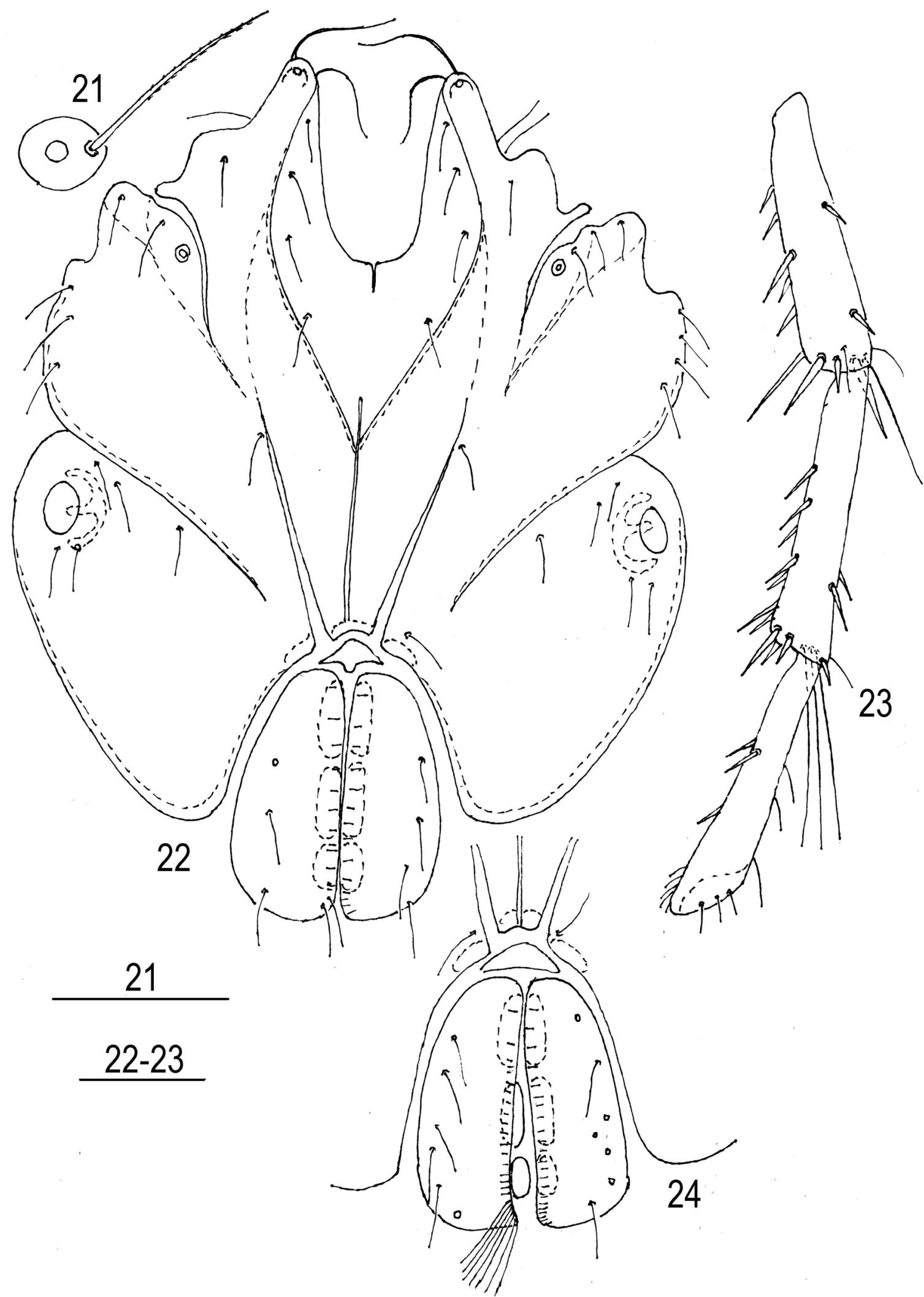

Figs. 21-24. Lebertia ussuriensis : 21-seta Fch; 22-coxal shield and genital field; 23-IV-Leg-4-6; 24-genital field; 21-23 - female; 24 - male. Scale bars: $21-50 \mu \mathrm{m}, 22-24-100 \mu \mathrm{m}$.

and occupying more than half ventral surface of idiosoma. Coxal plates I fused to each other nearly complete, fragment of suture line present only in their posterior portion. Suture line between coxal 


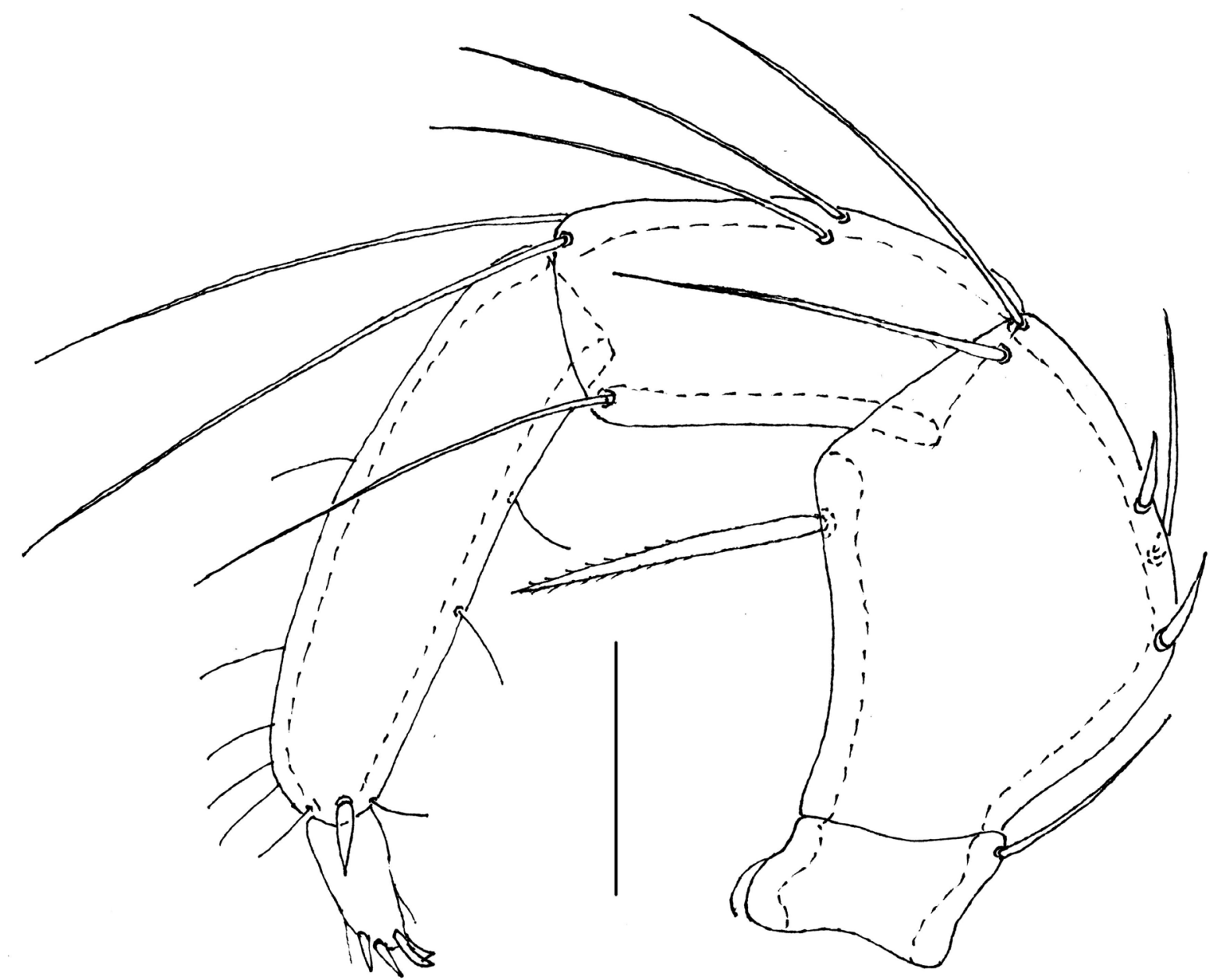

Fig. 25. Lebertia ussuriensis, female: pedipalp, lateral view. Scale bar $50 \mu \mathrm{m}$.

plates II a little larger than median length of coxal plates I or they occasionally equal in length $(\mathrm{Cx}-\mathrm{I} /$ Cx-II ratio 0.68-1.0). Coxal shield bearing two pairs of glandularia $(\mathrm{Hv}$ and $\mathrm{Pe}$ ), $\mathrm{Pe}$ located near tips of coxal plates I. Genital field consisting of two pairs acetabula, two very narrow lateral plates, usually with three pairs of setae (occasionally four setae on any side) and small pregenital sclerite. All acetabula subequal or posterior pair a little large than anterior pair. Excretory pore slightly sclerotized (Fig. 16).

Basal segment of chelicera with convex dorsal and nearly straight ventral margins (Fig. 17). Terminal part of chela pointed and with two rows of fine teeth.

Pedipalp compact (Fig. 18): P-1 short and without setae; P-2 with slightly concave ventral margin, bearing short, thick dorsal setae near middle of segment and two long dorsodistal setae; P-3 with two long dorsodistal setae; P-4 with straight ventral margin, bases of two ventral setae divided segment into three sectors: 1:1:1, 1:1:2 or
$1: 1: 3$, dorsal margin with single short proximal seta and four distal short, thin setae, distolateral spine pointed, its length about $1 / 2$ of P-5.

Legs 6-segmented. Legs III-IV with swimming setae, their number as following: 1-2 on III-Leg-5, 0-1 on IV-Leg-4 and 2 on IV-Leg-5 (Fig. 19). Claws of all legs with long pointed external and comparatively thick internal clawlets, lamella with convex ventral margin (Fig. 20).

Measurements $(\mathrm{n}=10)$. Idiosoma L 295-625; coxal plate L 240-315, W 225-270; coxal plates I $\mathrm{mL}$ 60-80; coxal plates II mL 80-95; acetabular plates L: 38-48; acetabula (ac-1-2) L: 12-18, 16-24; capitulum L: 100-105; cheliceral segments L: base 95-105, chela 22-26; pedipalp segments (P-1-5) L: 12-16, 40-48, 32-42, 44-56, 16-18; leg segments L: I-Leg-1-6: 32-36, 32-39, 41-48, 54-68, 60-68, 70-84; II-Leg-1-6: 33-39, 35-42, 40-48, 64-74, 67-93, 85-96; III-Leg-1-6: 38-45, 38-48, 48-55, 73-90, 95-115, 105-120; IVLeg-1-6: 67-80, 45-55, 73-80, 100-145, 118-145, 110-130. 
Both sexes. Integument soft and finely striated. Setae Fch (Fig. 21) longer and thicker than other idiosomal setae. Trichothria $\mathrm{Fp}, \mathrm{Oi}$ and setae $\mathrm{Pi}$ not associated with glandularia, other idiosomal setae associated with glandularia.

Coxal shield longer than wide (Fig. 22). Coxal plates I fused to each other nearly complete, fragment of suture line present only in their posterior portion. Suture line between coxal plates II a little larger than median length of coxal plates I, occasionally nearly equal in length $(\mathrm{Cx}-\mathrm{I} / \mathrm{CX}-\mathrm{II}$ ratio 0.83-0.95). Coxal shield bearing two pairs of glandularia $(\mathrm{Hv}$ and $\mathrm{Pe}), \mathrm{Pe}$ located near tips of coxal plates I. Posterior margin of coxal plates comparatively narrow . Coxal plates IV embracing the genital field $3 / 4$ to $2 / 3$, with obtuse-angled or rounded posteriomedial edges. Genital field with three pairs of acetabula, posterior pair smaller than anterior pairs of acetabula. Excretory pore as in deutonymph. Legs III-IV with swimming setae, their number as following: 1-2 on III-Leg-5 and IV-Leg-4, usually 3, occasionally 2 or 4, on IVLeg-5 (Fig. 23).

Pedipalp moderately long (Fig. 25): P-1 with single dorsodistal setae; P-2 with three unequal proximal and two long dorsodistal setae, ventral margin of segment concave, ventrodistal seta thick and shifted a little away from ventrodistal segment end; P-3 dorsal setae close to each other, inserted slightly proximally from center of segment, medioand dorsodistal setae close to each other, ventrodistal seta inserted near ventrodistal segment edge; P-4 with straight ventral margin, generally divided by seta insertions into three unequal sectors $2: 1: 2$, $2: 1: 3$ or $3: 2: 2$, mediodistal peg-like seta pointed, its length about $1 / 2 \mathrm{P}-5$.

Female. Genital field with $10-15$ pairs medial and 3-5 pairs lateral thin setae (Fig. 22). Measurements $(\mathrm{n}=5)$. Idiosoma L 625-1250; coxal shield 560-600, W 475-560; coxal plate I mL 125-145, coxal plate II mL150-170; genital flap L 185-200, W 75-85, genital acetabula (ac-1-3) L 62-70, 55-65, 37-45; cheliceral segments L: base 190200, chela 36-42; pedipalp segments (P-1-5) L: 27-30, 77-80, 72-78, 90-96, 27-30; leg segments L: Leg-1-6: 50-65, 65-80, 80-88, 115-125, 120 125, 125-140; II-Leg-1-6: 62-75, 73-78, 85-100, 135-150, 160-175, 150-160; III-Leg-1-6: 62-75, 78-90, 105-115, 150-175, 205-215, 160-200; IV-Leg-1-6: 110-140, 100, 100-105, 125-165, 200-225, 210-250, 200-215.

Male. Genital field with 20-25 pairs medial and 5-7 pairs lateral thin setae (Fig. 24). Measure- ments ( $\mathrm{n}=8$ ). Idiosoma L 600-875; coxal shield 550-565, W 475-525; coxal plate I mL 125-140, coxal plate II mL 140-155; genital flap L 135-145, W 60-65, genital acetabula (ac-1-3) L 40-50, 37-45, 25-35; cheliceral segments L: base 168 175, chela 24-30; pedipalp segments (P-1-5) L: 24-30, 65-72, 65-68, 82-86, 23-25; leg segments L: Leg-1-6: 50-65, 62-75, 75-80, 110-125, 110 130, 125-135; II-Leg-1-6: 62-75, 62-75, 75-80, 135-140, 145-155, 145-155; III-Leg-1-6: 65-87, 75-90, 100-115, 145-155, 185-200, 175-180; IV-Leg-1-6: 110-125, 85-100, 140-150, 185-200, 210-230, 200-215.

\section{DISCUSSION}

The water mite Lebertia ussuriensis is similar to L. fimbriata Thor, 1899. However, the following distinct differences can be found in the morphology of larva and adults of Lebertia ussuriensis (character states of larva and adult of L. fimbriata are given in parenthesis after Martin 2000 and Müller 2015 for larvae, Gerecke 2009 and Di Sabatino et al. 2010 for adults): larva: larvae do not parasitize (parasitic on chironomid Diptera: Chironominae, Orthocladiinae and Tanitarsini); dorsal plate broad, 190-200 $\mu \mathrm{m}$, Fig. 1 (comparatively narrow, 125$145 \mu \mathrm{m})$; excretory pore located near distal end of excretory pore plate, Figs. 2-6 (centrally located on excretory pore plate); III-Leg-2 with single heavy seta, Fig. 11 (two heavy setae); adults: IV-Leg-5 with three to four swimming setae, Fig. 19 (one to two swimming setae); IV-Leg-6 with three to four ventral spines (two ventral spines).

Habitat. Running waters.

Distribution. Asia, Russia, Far East, Primorye Territory (Sokolow 1934, 1940, Semenchenko 2008), Amur Province, Jewish Autonomous Region and Khabarovsk Territory (Semenchenko 2008), Kamchatka and Chukotka (my data).

\section{ACKNOWLEDGEMENTS}

This research was performed in the framework of the state assignment of FASO Russia (theme No 0122-2014-0007). The author expresses sincere gratitude to anonymous referees for reviewing the manuscript.

\section{REFERENCES}

Di Sabatino, A., Gerecke, R., Gledhill, T. and Smit, H. 2010. 8. Acari: Hydrachnidia II. In: R. Gerecke (Ed.). Süßwasserfauna von Mitteleuropa, 7/2-2. Spectrum Akademischer Verlag Heidelberg: 1-429. 
Gerecke, R. 2009. Revisional studies of the European species of the water mite genus Lebertia Neumann, 1880 (Acari: Hydrachnidia: Lebertiidae). Abhandlungen der Senckenberg Gesellschaft für Naturforschung, 566, 1-144.

Martin, P. 2000. Larval morphology and host-parasite association of some stream living water mites (Hydrachnidia, Acari). Archiv für Hydrobiologie. Suppl. 121, 269-320.

Martin, P., Dabert, M., Dabert, J. 2010. Molecular evidence for species separation in the water mite Hygrobates nigromaculatus Lebert, 1879 (Acari, Hydrachnidia): evolutionary consequences of the loss of larval parasitism. Aquatic Sciences, 32: 347-360.

Müller, H. 2015. Morphologie, Taxonomie und Parasitismus einiger Wassermilben larven und einiger Nymphe (Acari: Hydrachnidia) in der Saale (Thüringen). Lauterbornia, 80: 69-111.

Pešić, V., Asadi, M., Cimpean, M., Dabert, M., Esen, Yu., Gerecke, R., Martin, P., Savić, A., Smit, H. and Stur, E. 2017. Six species in one: evidence of cryptic speciation in the Hygrobates fluviatilis complex (Acariformes, Hydrachnidia, Hygrobatidae). Systematic and Applied Acarology, 22 (9): 1327-1377.

Semenchenko, K.A. 2008. The history of water mites study (Acari, Hydrachnidia) of the Russian Far East. Vladimir Ya. Levanidov's Biennial Memorial Meetings, 4: 152-163. [In Russian]

Sokolow, I.I. 1934. Beiträge zur Kenntnis der Hyrdacarinenfauna des Ussuri=Gebiets. II. Hydracarinen der fließenden Gewässer. Zoologisher Jahrbücher, 65 (3-4): 309-388.

Sokolow, I.I. 1940. Hydracarina. Vodyanye kleshchi. Chast' I. Hydrachnellae. Fauna SSSR (novaya seriya No 20). Paukoobraznye, 5 (2) [Hydracari$n a$-the aquatic mites. Part I. Hydrachnellae]. Nauka, Moscow-Leningrad, 24 pp.+511. [In Russian]

Tuzovsky, P.V. 1987. Morfologiya i postembrional'noe razvitiye vodyanykh kleshchej [Morphology and Postembryonic Development in Water Mites]. Nauka, Moscow, 172 pp. [In Russian] 